\title{
Education, equality and difference ${ }^{1}$
}

\author{
Penny Enslin \\ Department of Education \\ University of the Witwatersrand \\ JOHANNESBURG
}

\begin{abstract}
Does the pursuit of equality in post-apartheid education require the removal of difference? This article examines the concepts of difference and equality by exploring wo contemporary texts in political philosophy. It is argued that the pursuit of equality can and should, under certain circumstances, accommodate difference in the form of decentralisation and private schools.
\end{abstract}

\section{Introduction}

Most political parties and movements in South Africa now accept, as the outcome of negotiations, a unitary democratic state with a common citizenship for all and a degree of decentralisation to nine regions. It is widely, although not universally, agreed that a single state is needed to provide the authority and resources necessary to initiate and control a process of redistribution of social goods, including education, to remove historical inequalities.

Since the process of negotiation towards a post-apartheid era began, it has also been commonly assumed that in place of an educational system based on difference and extreme inequalities, we will need one which tries with vigour to redress inequality. Critics of education under apartheid emplasised the inequalities in South African education, drawing attention to differences in access and outcomes between white and black schooling. For some critics the justification for these inequalities was reflected until fairly recently in official policy - a policy which was seen to justify both segregation, assuming that there should be different education for different groups, and differences in provision. The schooling system became a focus for mass protest against segregation and inequality.

1 An carlicr version of this paper was presented at the VIIIth World Congress of Comparative Education Societics, Charles University, Prague, July 1992 
The question which this article sets out to address is: if the differences inherent in apartheid education produced inequality, must post-apartheid educational policy try to remove difference in its quest for greater equality? Freer (1992:4) for example, writes that "the strategy for the next decade must surely be aimed at the eradication of both material and perceived differences". This could be interpreted as an assertion that in the pursuit of equality we will need to remove as many of the differences in the education provided for all South African children as we can.

Current perspectives on equality and difference in South African education policy focus on two related themes. The one theme is the question of whether a future education system should be highly centralised or decentralised. Some would wish to argue that only a centralised system, in terms of factors which include funding and the curriculum, can effectively carry out a policy of equalising access to and outcomes of schooling. Others would claim that only a decentralised system can cater for cultural and regional diversity. The second theme is the future of private schooling in South Africa. While the National Party government did not encourage private schooling in the period after its election victory in 1948, its policy seemed to change with the Private Schools Act of 1986 and the introduction of the Clase Models in 1990, subsequently revised, which have allowed some white schools the option of becoming private or semi-private schools. Those who favour these developments defend such schools as a means of allowing cultural minorities to exercise greater autonomy in the provision of education for their children. For their opponents, such schools entrench inequality by handing over state-owned facilities to already privileged communities.

This article will argue, from the perspective of normative political philosophy, that in the new democratic form of public life which we seek, premised on the common good, a commitment to equality is not a commitment to sameness, or to the rejection of difference. I refer to difference as social or group difference, including cultural or ethnic difference, as against material differences in the provision of funding and facilities. In arguing that a future educational system can both promote equality and accommodate difference, the article will begin by exploring a current feminist perspective on difference and equality in the work of Iris Young. This view will then be connected with Michael Walzer's idea of complex equality, as a way of reconciling difference and equality in a future South African educational system. The implications for South African education of these two views of equality, written about American society, will be explored. 


\section{Difference and justice}

\subsection{Group difference and equality}

Recent feminist scholarship has stimulated new debate on a range of issues in social theory. Iris Young's work on difference and gender (1990a, 1990b) opens up fresh perspectives on difference in the broader political context. I will suggest that her problematisation of distributive justice and universal citizenship, and her treatment of the significance of group difference offer an instructive view of the problems on which this article focuses.

Young argues for an alternative to the usual construal of justice as a distributive matter. The distributive paradigm emphasises a notion of justice as the allocation of material goods or social positions at the expense of social, non-material goods including "decision-making power and procedures, division of labour, and culture" (Young, 1990a:15). While she accepts that distributive questions do have a place in an acceptable theory of justice, Young's concern is the tendency to reduce problems of social justice to distributive issues. She defends a social ontology which expresses the feminist themes of relations and processes, rather than things, as central to an enabling conception of justice:

Justice should refer not only to distribution, but also to the institutional conditions necessary for the development and exercise of individual capacities and collective communication and cooperation (Young, 1990a:39).

A further problem with contemporary theories of justice is their association with the ideal of the universal, homogeneous civic public. The ideal of universal citizenship insists that laws and rules should be "the same for all and apply to all in the same way" (Young, 1990b:114) - which perpetuates injustice by emphasising what citizens share in common rather than how they are different. Defending the notion of a differentiated, heterogeneous public, she argues instead that where there are social group differences, where some groups are oppressed and others privileged, oppression is more likely to be undermined if group differences are acknowledged. Arguing that group differentiation is not only inevitable but also desirable, Young calls for a politics that attends to group difference rather than trying to repress it. The primary principle of justice is the equal treatment of groups.

Young defines a social group not in the first instance by some shared attribute, but by a common sense of identity held by its members. "...[I]t is identification with a certain social status, the common history that social status produces, and self-identification that define the group as a group" (Young, 1990a:44). 
I argue that sometimes recognizing particular rights for groups is the only way to promote their full participation. Some fear that such differential treatment again stigmatises these groups ... this is true only if we continue to understand difference as opposition - identifying equality with sameness and difference with deviance or devaluation (Young, 1990a:11).

Young cites as examples of social movements which have held that it is more liberatory to assert group difference: American Indians, women, gays, lesbians, old people, black and Hispanic Americans, and the disabled. Rejecting an assimilationist ideal, she observes that in the "democratic cultural pluralism" (Young, 1990a:174) which is implicit in the assertion of a positive sense of group difference by these emancipatory movements, the good society is not one which transcends or eliminates group difference. In the good society, there is respect between socially and culturally differentiated groups, whose differences are mutually affirmed. Formal equality is insufficient as it does not remove social differences, and it can have oppressive consequences, for "rhetorical commitment to the sameness of persons makes it impossible even to name how those differences presently structure privilege and oppression" (Young, 1990a:164). Hence Young's defence of a politics of group assertion, in which oppressed groups are organised separately and others, especially the more privileged, are excluded.

This does not mean that Young would sanction all possible politics based on group difference, which can also have an oppressive meaning when defined as "absolute otherness, mutual exclusion, categorical opposition" (Young 1990a: 169). For South Africans pondering how to respond to difference after apartheid, Young's analysis is illuminating, for apartheid, and its accompanying schooling system, was founded on an ideology of difference as exclusion, opposition and absolute otherness. For those of us whose impulse might consequently be to deny difference, it is important to note Young's observation that difference as exclusion and opposition is actually a denial of difference because universalizing norms prevent the recognition and affirmation of a group's own specific identity. What Young calls the politics of difference is a means of confronting a fear of specificity, not by essentializing difference, but by trying to develop an understanding of group difference as shifting and ambiguous. In accommodating a heterogeneous public in a just polity, group difference would be publicly acknowledged rather than ignored. A heterogeneous, democratic public would publicly discuss issues and make decisions based on principles of justice.

Even more so should group differences of nation or ethnicity be accepted. In the twentieth century the ideal state is composed of a plurality of nations or cultural groups, with a degree of self-determination and autonomy compatible with federated equal rights and obligations of citizenship (Young, 1990a:180). 


\subsection{Group difference and education in South Africa}

Young's treatment of equality and difference raises fundamental and difficult problems in the South African context. It is a theory open to abuse by apologists for continued white privilege. But it is also a challenge to confront difference at a time when it seems safer to avoid the issue and declare instead a vision of a homogeneous public. Her critique of justice perceived simply as a question of the distribution of goods warns us that creating equality in South African education is not only a matter of equal material provision of facilities, of removing differences in provision. It should also be understood as a relational, social issue concerned with equal development of collective capacities, as an issue concerning difference. To assume that we have a universal, undifferentiated public would be to ignore this.

While acknowledging and fostering group difference does provide an imperative to consider the fact that within the educational system certain groups might be more justly treated if they are recognised rather than if they are subsumed as part of a homogeneous public, this does not necessarily imply that each group must have its own schools. Nor does it require that private schools should be provided for those who choose to attach educational significance to membership of a group, an option in any case less likely to be available to groups without the necessary financial resources. But it does have a bearing on the question of the continued existence of private and indeed state schools - especially religious schools - that offer access to membership of a group, subject to their publicly putting their case for special provision. While Young's concern is the oppressed, and she would not regard whites or Afrikaners, for example, as oppressed, it is not unreasonable to claim that her concerns will be applicable to such minorities once they share power with others. Furthermore, once the primary issue in South African politics is no longer a confrontation largely between black and white, other minorities may emerge claining a need for differentiated citizenship. Young's rejection of equality as sameness is especially pertinent to the issue of gender. An educational system that sets out to provide equal education for girls will fail if it is merely distributive, offering them the same formal access as boys. Among other things, it will have to take drastic steps to address problems of sexual harassment of girls in many schools, possibly by means of separate education in some areas.

\section{Complex equality}

\subsection{Educational goods}

In his Spheres of Justice (1983) Michael Walzer proposes an alternative to 'simple' or literal equality, where everyone has the same share of social goods 
like wealth, power or education. In most societies there is a dominant good or goods which define the value of goods in other spheres. Dominance prevails when a group of people acquires a monopoly over a dominant good. For example, in capitalist societies wealth is dominant and determines the value of other goods, allowing those who possess it to convert it into other social goods such as office and political power. The use of social goods is not limited to their intrinsic meaning, but some people are able to monopolise social goods in order to benefit from their dominance by commanding other goods. As neither monopoly nor dominance is ever complete, however, the ruling class is inevitably challenged by others, who want to set up different ways of converting goods.

Arguing that political egalitarianism aims at achieving a society which is free from domination, and taking criticism of the structures and relationships of dominance as the task of a theory of justice, Walzer describes as complex equality a set of relationships under which domination is not possible. As domination is mediated by social goods, people could be considered equal when social goods are controlled so that they cannot act as a means of domination. Under complex equality Walzer proposes that there would be separate, autonomous spheres of justice, dominance being reduced by restricting the convertibility of goods from one sphere to another. Within each sphere inequalities may have to be allowed. So the form of the principles of justice is pluralistic because the reasons for distributing various social goods will differ, and their distribution will follow differing procedures conducted by different agents. Walzer proposes the distributive principle that:

No social good $\mathrm{x}$ should be distributed to men and women who possess some other good $y$ merely because they possess $y$ and without regard to the meaning of $x$ (Walzer, 1983:20).

Education is one of the social goods which Walzer discusses in developing his theory of justice. He suggests that schooling is a social good which requires its own set of processes of distribution. Schools and educational authorities, in turn, have to distribute appointments of teachers, admission of students to schools, authority, marks and promotions, and knowledge itself. If these are to be done in accordance with principles of complex equality, rather than dominance and monopoly, the patterns of distribution "cannot simply mirror the patterns of the economy and political order, because the goods in question are different goods" (Walzer, 1983:198).

In asking how schooling should be distributed, Walzer sympathises to some extent with Aristotle's view that "the system of education in a state must be one and the same for all, and the provision of this system must be a matter of public action" (Walzer, 1983:202). His agreement includes endorsement of the view that education in a democracy requires that all should be able to grasp a common core 
curriculum. Once the core has been grasped, simple equality is no longer appropriate and individual abilities and interests should be allowed to shape education, including specialized provision to match those abilities and interests.

For Walzer the wider community's commitment to democracy can be matched by democratic practices in schools, if schools are autonomous spheres within the community. He is attracted by the argument that "schools can provide a genuinely common education only if they are protected from corporate and governmental intrusion" (Walzer, 1983:207), which are likely if allowed to intervene to effect an unequal distribution of educational goods.

Proposing the general principle that schools should try to create a pattern of association which anticipates that in which adult men and women are participants, Walzer allows that there could be a number of kinds of institutions and patterns of association apparently compatible with the education of democratic citizens, and "neither compulsory education nor a common curriculum requires that all children go to the same sorts of school or that all schools stand in the same relation to the political community" (Walzer, 1983:217).

Although Walzer argues for the importance of public debate and that educational goods should be communally provided, he seems prepared to allow some role for private schooling - provided it is not controlled solely by parents and entrepreneurs.

I don't think that there is any need for a frontal assault on parental choice, so long as its chief effect is to provide ideological diversity on the margins of a predominantly public system. In principle, educational goods should not be up for purchase, but the purchase is tolerable if it doesn't carry with it (as it still does, for example, in Britain today) enormous social advantages. Here, as in other areas of communal provision, the stronger the public system, the easier one can be about the uses of money alongside it. Nor is there much reason to worry about those private schools that provide specialized education, as long as scholarships are available, and as long as there are alternative routes to public and private office (Walzer, 1983:219).

\subsection{Complex equality and the future of schooling in South Africa}

How can Walzer's theory of equality help us to deal with moral problems about inequality and difference in South African education? South African society, as a distinctive example of what Walzer calls dominance, has seen a ruling class acquire and extend its monopoly over a set of dominant goods which include wealth and birth, which have in turn been converted into other social goods, including office, political power and - strikingly - education. As a particularly prominent feature of the South African crisis, schooling as a social good has been monopolised by whites as a result of their monopoly over other social goods. And the 
challenge mounted by the oppressed against the dominance of the ruling class has focused strongly on this sphere of injustice, though it should be added that the strategic collapse of the distinction between the spheres of education and political power is a major factor in the present breakdown of authority and learning in many schools.

It is salutary to consider what simple equality would require if applied in a policy of redistribution of educational goods. Simple equality in the sphere of sclooling would require drastic state intervention to equalise access and outcomes. Resources and facilities would have to be taken away from some schools and reallocated to others. Schools with better equipment and better-qualified teachers might have to be penalised so that their students do not continue to benefit from the schooling system more than those with access to less satisfactory provision. It would be necessary to act against schools or even parents who, after an initial re-allocation of resources, continue to prosper more than others, which in turn would require careful and detailed monitoring of all school and extra-school activities.

Such a vision of equality would, if feasible at all, come at a price many of us would not be prepared to pay. But if we opted for complex equality, how much parental choice and diversity could there be? What if, for example, a significant proportion of the Afrikaans-speaking population want to argue that provision could be made for private or even state Christian schools with a strong emphasis on Afrikaans language and culture within a system of complex equality? What of special provision for Muslim girls or for Jewish children?

From the point of view of complex equality, it must be possible to defend such different provision, provided what Walzer calls the core is available to the masses. A further proviso would be that in principle the parents of children receiving such special provision are not thereby able to reproduce inequalities by buying for their children the advantage of converting their education into other social goods in ways that are clearly denied to other children

Walzer's idea of education as a social good is not one-dimensional. He does not see education as a good whose sole purpose is conversion into other goods like office, wealth or power - though he emphasises that in an unequal society that is how it works for some. He also sees schools as places where children can learn to be participating members of democratic societies. And he correctly sees education as a means for parents to bring their children up as members of particular 'communities of understanding'. It is conceivable that, provided schooling is not inappropriately convertible into other social goods, various Christian schools, for example, could be allowed to provide access to a particular community of understanding, though a problem for Walzer's theory is that the education provided as access to some communities of understanding is likely to enable members of 
some communities to convert their education into other social goods such as office. A difficulty that must be recognised is that creating equality in the spliere of education, in terms of Walzer's theory, depends on factors in other spheres which are beyond the influence of those active in the educational spinere. Furthermore, while achieving complex equality in the sphere of education depends on the creation of a strong state educational sector, the private or specialized state schools cannot themselves achieve this, although they can influence such a process by sharing curriculum innovations and even some of their resources.

\section{Conclusion}

Having reflected on the central features of Young's theory of difference and Walzer's notion of complex equality in relation to Soutl African education, we return to the question: must post-apartheid educational policy aim to remove difference in a quest for equality? This paper has argued against a strategy of removing difference. Examination of the concepts of difference and equality makes it clear that, problematic though the issues are, it is possible and desirable to pursue equal education while respecting difference.

\section{Bibliography}

FREER, D. ed. 1992. Towards Open Schools. Manzini : Macmillan Boleswa

WALZER, M. 1983. Spheres of Justice. Oxford : Basil Blackwell.

YOUNG, I.M. 1990a. Justice and the Politics of Difference. Princeton: Princeton University Press.

YOUNG, IM. 1990b. Throwing Like a Girl and other Essays in Feminist Philosophy and Social Theory. Bloomington: Indiana University Press 
